\title{
PREVALENCE, ETIOLOGY AND RISK FACTORS FOR FALLS IN NEUROLOGICAL PATIENTS ADMITTED TO THE HOSPITAL IN NORTHERN TURKEY
}

\author{
Zeliha Koç ${ }^{1}$ Ayşegül Memiş² and Zeynep Sağlam ${ }^{1}$ \\ ${ }^{1}$ Ondokuz Mayıs University Health Science Faculty, Ondokuz Mayis University Campus, Samsun, Turkey; \\ ${ }^{2}$ Gazi State Hospital, Samsun, Turkey
}

\begin{abstract}
SUMMARY - This study was carried out to determine the prevalence of falls, their etiology and risk factors in neurological patients admitted to the hospital in northern Turkey. A cross-sectional, descriptive design was used. Data were collected by survey that identified socio-demographic and clinical features of the subjects, Hendrich II fall risk model and Berg Balance Scale (BBS). Study results revealed approximately one-third of the study patients (33.1\%) to have sustained falls before. Concerning the timing of falls, $24.9 \%$ of these incidents had occurred within the last year. The most common reason for falling was dizziness (14.3\%). The mean score on the Hendrich II fall risk model was $2.7 \pm 0.1$ for those who had fallen and $2.3 \pm 0.1$ for those who had not fallen. The respective mean BBS score was $20.7 \pm 1.9$ and $18.4 \pm 1.3$. It was found that approximately one-third of neurological patients had fallen before and had restricted their activities due to fear of falls; the great majority of them had a chronic disease and permanently used medicines; and the most important risk factors for falls were advanced age, fear of falls and impaired balance.
\end{abstract}

Key words: Balance; Etiology; Fall; Neurology; Prevalence; Prevention; Risk

\section{Introduction}

Falls are common health problems, which might result in significant injuries and complications in health care settings, extend hospitalization, decrease functional capacity of patients and increase health care costs $^{1}$. Giles et al. report that falls were the most common critical event reported in inpatients that led to tragic outcomes affecting mortality and morbidity ${ }^{2}$. A previous research found that accidental falls in inpatients caused serious injuries and complications ${ }^{1}$. Falls might be affected by various factors in inpatients. Healey reports that falls among inpatients were caused by a combination of many risk factors involving acute

Correspondence to: Prof. Zeliha Koç, PhD, Ondokuz Mayıs University Health Science Faculty, Ondokuz Mayis University Campus, 55139 Samsun, Turkey

E-mail: zelihaceren@hotmail.com

Received June 8, 2016, accepted June 20, 2017 diseases and long-term effects of these diseases, the process of aging, and adverse effects of medication and hospital environment unfamiliar to patients ${ }^{3}$. Lovallo et al. report that the majority of patients were exposed to many risk factors and therefore they would probably experience falls, while the nature and prevalence of these factors varied in different hospitalized groups ${ }^{4}$. In another study, it was found that the fall risk profiles of inpatients varied when compared to those in the community; that hospital setting was much different from house setting; and that inpatients were generally more frail due to hospitalization ${ }^{2}$.

Previous studies on falls report that neurological patients had a high risk of falling ${ }^{5}$, and that falls were more prevalent in neurological services ${ }^{6,7}$. Hunderfund et al. found the rate of falls in neurology departments to be 5.69 per 1000 patients/day, with neurological inpatients to have a high percentage of falls ${ }^{8}$. Albernaz and Dos Santos Cabral report that $32.5 \%$ of their 
study participants had fallen before; $60 \%$ of them fell accidentally, 20\% fell due to neurological disorder and another $20 \%$ due to vestibular disorder, while $40 \%$ had neurological disorder and vertigo. They also report that vertigo, imbalance and dizziness were very common in individuals with neurological disorder'. Stolze et al. found falls in neurological patients to be linked with disorders affecting gait and balance and use of medication $^{10}$.

\section{Aim}

There is a lack of epidemiological data on falls concerning risk factors and characteristics of neurological patients that affect proneness to falls among neurological patients in northern Turkey. This situation stimulated our embarking upon this study. The present study aimed to determine the prevalence of falls, their etiology and risk factors in neurological patients admitted to the hospital. The research was expected to answer the following questions:

- What is the prevalence of falls, their etiology and risk factors among neurological patients?

- What is the balance status among neurological patients?

- What characteristics of neurological patients affect the fall situation?

\section{Patients and Methods}

\section{Study design and sampling method}

A cross-sectional, descriptive design was used to determine the prevalence of falls, their etiology and risk factors in neurological patients. It was carried out at a hospital neurology department between May 20, 2011 and April 30, 2012 in Samsun province in northern Turkey. A total of 534 patients were admitted to the department as inpatients during the study. The authors aimed to recruit the entire population of patients admitted to the hospital neurology service due to various neurological problems. However, patients who were not willing to participate in the study $(n=24)$, who failed to complete the questionnaire and did not respond clearly to the questions $(\mathrm{n}=12)$, and who were unconscious $(\mathrm{n}=253)$ were excluded. The study included 245 patients who gave their consent to take part in the study. The response rate was $45.9 \%$. All subjects were able to answer the questions independently and had no memory problems.

The sample criteria were as follows: age $\geq 18$ years; admission to the neurology department as inpatients; being able to communicate verbally with us; being able to understand the study and provide their informed consent; not taking any psychiatric drugs that would affect his/her mental status; not being too confused to complete the questionnaire; and being able to read and write, a literacy level education. Exclusion criteria were as follows: bedridden and unconscious patients; mental or legal incapacity to provide an informed consent; having communication difficulties (inability to speak) or cognitive impairment; terminal illness; and history of illness or a condition that would affect balance test (e.g., disability).

\section{Procedures}

Data were collected via a questionnaire prepared by the researchers to determine the patient socio-demographic and clinical specifications, in addition to the Hendrich II fall risk model and the Berg Balance Scale (BBS). The study commenced upon approval granted by the Hospital Scientific Committee. The study followed the principles of the Declaration of Helsinki. We obtained consent from each study participant. This process was carried out in a separate room by the researchers. In the data collection phase, the aims of the research were explained to the patients and their willingness to participate was ensured. Before data collection, the questionnaire was tested in a pilot study on a group of 10 patients. The response and practice time was estimated to $25-30 \mathrm{~min}$.

\section{Instruments}

Data were collected using a questionnaire. The first part of the questionnaire contained 30 questions on the patient socio-demographic characteristics, clinical characteristics, and fall characteristics (e.g., status of having fear of falling, the place where they mostly have fear of falling, taking precautions against falling at home, conditions of restricting activities due to fear of falling, condition of experiencing falling incident before, fall time, when the fall occurred, hours of falling, the place where the incident of falling occurred, reasons for falling, states aftermath falling, and number of falling incidents). 
Socio-demographic factors collected in the study included age, gender, marital status, education level, family type (large or nuclear), and living arrangements (living with a spouse, family member, or alone). In this study, a city referred to an urban area that was the largest residential area. A town referred to a semi-urban area with an approximate population of 5,000 to 10,000 people. A village was a rural area with an approximate population of 2,000 to 3,000 people. The sample was stratified by age (40-51,52-63, 64-75, and 76-88 years). Sex was coded as male or female. Marital status was married or single. The study grouped educational levels as literate, elementary school, secondary school, high school, and university.

Clinical characteristics and health behaviors included any chronic illnesses, previous hospitalizations, having a sensory disorder (yes/no), and type of sensory disorders (visual or auditory). Researchers asked about the subject perception of health. Respondents rated their own current health as good, fair, or poor. Data were also collected using the Hendrich II fall risk model and BBS.

\section{Hendrich II Fall Risk Model}

The Hendrich II fall risk model is fast to administer and provides determination of the risk of falling ${ }^{11,12}$. The validity and reliability of the Hendrich II fall risk model were tested for Turkish samples by Atay et al. in $2009^{13}$. They assessed data using appropriate statistical methods and found the kappa values obtained for the first seven items on the scale to range from 0.77 to 1.00 . The Spearman's rho value obtained for the eighth item, related to standing up and walking, was 0.91 . The reliability of the Turkish version of the Hendrich II fall risk model was found to be acceptably high in their study ${ }^{13}$. In our study, the alpha coefficient for patients was 0.79 .

\section{Berg Balance Scale}

Balance was measured using the BBS ${ }^{14,15}$. The validity and reliability of the BBS were tested for Turkish samples by Sahin et al. in 2008. In their research, internal consistency (Cronbach's alpha) of the BBS total score was calculated as $0.93^{16}$. In our study, the alpha coefficient for patients was 0.85 .

\section{Data analysis}

On data evaluation, percentage calculation, oneway ANOVA, Student's t-test, Pearson correlation analysis, and logistic regression analysis were used.

\section{Results}

\section{Sample characteristics}

Study results revealed that $37.6 \%$ of the subjects were $64-75$ years of age; $53.9 \%$ were female and $46.1 \%$ were male; $86.1 \%$ were married; $58.8 \%$ were literate; $62.0 \%$ had income less than expenses; $90.2 \%$ did not work; $70.2 \%$ had a nuclear family; $97.6 \%$ had social security; $35.5 \%$ lived with a spouse; and $49.8 \%$ lived in a city (Table 1).

\section{Clinical characteristics}

In this study, $75.5 \%$ of patients reported that their health condition was fair; $89.8 \%$ had chronic disease; 20.4\% had diabetes: $46.5 \%$ had hypertension disease; 83.3\% had been previously hospitalized; $29.4 \%$ had a sensory disorder: $21.2 \%$ had a visual disorder; and $89.8 \%$ used maintenance medicines for chronic diseases (Table 2).

\section{Falling status among neurological patients}

Study results showed that $32.2 \%$ of study patients had a fear of falling, mostly while having bath; $72.2 \%$ took precautions against falling at home; $14.3 \%$ restricted their activities because they were afraid of falling; and $33.1 \%$ had fallen during the previous three years. For the falls, $24.9 \%$ of the falling incidents occurred in the last year, $21.6 \%$ of the falling incidents occurred at daytime and $12.2 \%$ occurred in the afternoon. The most common reason for falling was dizziness (14.3\%) and 7.3\% had a lesion after falling (Table 3 ).

\section{Balance status and falling risk among neurological patients}

In the present study, $11.4 \%$ of neurological patients had a high risk of falling. The mean score on the Hendrich II fall risk model was $2.4 \pm 0.1$. The mean score on the Hendrich II fall risk model was $2.7 \pm 0.1$ for those who had fallen and $2.3 \pm 0.1$ for those who had not fallen, yielding no statistically significant difference between the two groups $(t=1.590, p=0.116)$. The mean score on the BBS among all neurological patients was $19.2 \pm 1.1$, with $89.0 \%$ scoring $\leq 45$ points. The mean BBS score was $20.7 \pm 1.9$ for those who had fallen and $18.4 \pm 1.3$ for those who had not fallen, thus yielding no statistically significant difference between the two groups ( $\mathrm{t}=1.027, \mathrm{p}=0.308$ ) (Fig. 1 ). 
Table 1. Demographic characteristics of patients $(N=245)$

\begin{tabular}{|c|c|c|}
\hline Characteristic & $\mathrm{n}$ & $\%$ \\
\hline Age group (years) & \multicolumn{2}{|c|}{$66.5 \pm 0.9$} \\
\hline $40-51$ & 28 & 11.4 \\
\hline $52-63$ & 48 & 19.6 \\
\hline $64-75$ & 92 & 37.6 \\
\hline $76-88$ & 77 & 31.4 \\
\hline \multicolumn{3}{|l|}{ Gender } \\
\hline Female & 132 & 53.9 \\
\hline Male & 113 & 46.1 \\
\hline \multicolumn{3}{|l|}{ Marital status } \\
\hline Married & 211 & 86.1 \\
\hline Single & 34 & 13.9 \\
\hline \multicolumn{3}{|l|}{ Education } \\
\hline Literate & 144 & 58.8 \\
\hline Primary school & 60 & 24.5 \\
\hline Secondary school & 14 & 5.7 \\
\hline High school & 21 & 8.6 \\
\hline University & 6 & 2.4 \\
\hline \multicolumn{3}{|l|}{ Socioeconomic status } \\
\hline Income less than expenses & 152 & 62.0 \\
\hline Income equal to expenses & 85 & 34.7 \\
\hline Income more than expenses & 8 & 3.3 \\
\hline \multicolumn{3}{|l|}{ Working status } \\
\hline Yes & 24 & 9.8 \\
\hline No & 221 & 90.2 \\
\hline \multicolumn{3}{|l|}{ Family type } \\
\hline Large & 73 & 29.8 \\
\hline Nucleus & 172 & 70.2 \\
\hline \multicolumn{3}{|l|}{ Social security } \\
\hline Present & 239 & 97.6 \\
\hline Absent & 6 & 2.4 \\
\hline \multicolumn{3}{|l|}{ Living with } \\
\hline Spouse & 87 & 35.5 \\
\hline Spouse and children & 73 & 29.8 \\
\hline Children & 72 & 29.4 \\
\hline No one & 13 & 5.3 \\
\hline \multicolumn{3}{|l|}{ Place of residence } \\
\hline City & 122 & 49.8 \\
\hline Town & 63 & 25.7 \\
\hline Village & 60 & 24.5 \\
\hline
\end{tabular}

Table 2. Clinical characteristics of patients $(N=245)$

\begin{tabular}{|c|c|c|}
\hline Characteristic & $\mathrm{n}$ & $\%$ \\
\hline \multicolumn{3}{|l|}{ Type of neurological disorder } \\
\hline Cerebrovascular disease & 168 & 68.6 \\
\hline Vertigo & 22 & 9.0 \\
\hline Epilepsy & 11 & 4.5 \\
\hline Headache & 9 & 3.7 \\
\hline Alzheimer's disease & 9 & 3.7 \\
\hline Multiple sclerosis & 7 & 2.8 \\
\hline Dementia & 16 & 6.5 \\
\hline Parkinson's disease & 3 & 1.2 \\
\hline \multicolumn{3}{|l|}{ Perceived health } \\
\hline Good & 33 & 13.5 \\
\hline Fair & 185 & 75.5 \\
\hline Poor & 27 & 11.0 \\
\hline \multicolumn{3}{|l|}{ Chronic disease condition } \\
\hline Yes & 220 & 89.8 \\
\hline No & 25 & 10.2 \\
\hline \multicolumn{3}{|l|}{ *Has chronic illness } \\
\hline Hypertension & 114 & 46.5 \\
\hline Diabetes & 50 & 20.4 \\
\hline Coronary arterial disease & 17 & 6.9 \\
\hline Renal failure & 3 & 1.2 \\
\hline Asthma & 8 & 3.3 \\
\hline $\begin{array}{l}\text { Chronic obstructive pulmonary } \\
\text { disease }\end{array}$ & 12 & 4.9 \\
\hline Others & 8 & 3.3 \\
\hline \multicolumn{3}{|l|}{ Previous hospitalization } \\
\hline Yes & 204 & 83.3 \\
\hline No & 41 & 16.7 \\
\hline \multicolumn{3}{|l|}{$\begin{array}{l}\text { Status of heaving sensory } \\
\text { disorder }\end{array}$} \\
\hline Yes & 72 & 29.4 \\
\hline No & 173 & 70.6 \\
\hline \multicolumn{3}{|l|}{ *Sensory disorders $(n=72)$} \\
\hline Visual & 52 & 21.2 \\
\hline Auditory & 11 & 4.5 \\
\hline Visual-auditory & 9 & 3.7 \\
\hline \multicolumn{3}{|l|}{$\begin{array}{l}\text { Status of using continuous } \\
\text { medicine }\end{array}$} \\
\hline Yes & 220 & 89.8 \\
\hline No & 25 & 10.2 \\
\hline
\end{tabular}

*More than one answer given. 
Table 3. Distribution of patient features according to falling incidents $(N=245)$

\begin{tabular}{|c|c|c|}
\hline Characteristic & $\mathrm{n}$ & $\%$ \\
\hline $\begin{array}{l}\text { Having fear of falling } \\
\text { Yes } \\
\text { No }\end{array}$ & $\begin{array}{l}79 \\
166 \\
\end{array}$ & $\begin{array}{l}32.2 \\
67.8\end{array}$ \\
\hline $\begin{array}{l}\text { *The place where patients } \\
\text { mostly had fear of falling }(\mathrm{n}=79) \\
\text { While going downstairs } \\
\text { While having bath } \\
\text { Other }\end{array}$ & $\begin{array}{l}27 \\
39 \\
18\end{array}$ & $\begin{array}{l}11.0 \\
15.9 \\
7.3\end{array}$ \\
\hline $\begin{array}{l}\text { Taking precaution against } \\
\text { falling at home } \\
\text { Yes } \\
\text { No }\end{array}$ & $\begin{array}{l}177 \\
68\end{array}$ & $\begin{array}{l}72.2 \\
27.8\end{array}$ \\
\hline $\begin{array}{l}\text { *Precautions taken against } \\
\text { falling at home }(\mathrm{n}=177) \\
\text { Grab irons on the stairs } \\
\text { Grab irons in the bathroom and } \\
\text { toilet } \\
\text { Smooth floor surface } \\
\text { Anti-skid matting in the } \\
\text { bathroom }\end{array}$ & $\begin{array}{l}153 \\
3 \\
21 \\
60\end{array}$ & $\begin{array}{l}62.4 \\
1.2 \\
8.6 \\
24.5\end{array}$ \\
\hline $\begin{array}{l}\text { Restricting activities due to fear } \\
\text { of falling } \\
\text { Yes } \\
\text { No }\end{array}$ & $\begin{array}{l}35 \\
210\end{array}$ & $\begin{array}{l}14.3 \\
85.7\end{array}$ \\
\hline $\begin{array}{l}\text { Having experienced falling } \\
\text { incident before } \\
\text { Yes } \\
\text { No }\end{array}$ & $\begin{array}{l}81 \\
164\end{array}$ & $\begin{array}{l}33.1 \\
66.9\end{array}$ \\
\hline $\begin{array}{l}\text { Fall time }(\mathrm{n}=81) \\
\text { Night } \\
\text { Daytime }\end{array}$ & $\begin{array}{l}28 \\
53\end{array}$ & $\begin{array}{l}11.4 \\
21.6\end{array}$ \\
\hline $\begin{array}{l}\text { When the fall occurred? }(\mathrm{n}=81) \\
\text { Last year } \\
1 \text { year ago } \\
2 \text { years ago } \\
3 \text { years ago }\end{array}$ & $\begin{array}{l}61 \\
4 \\
8 \\
8\end{array}$ & $\begin{array}{l}24.9 \\
1.6 \\
3.3 \\
3.2\end{array}$ \\
\hline
\end{tabular}

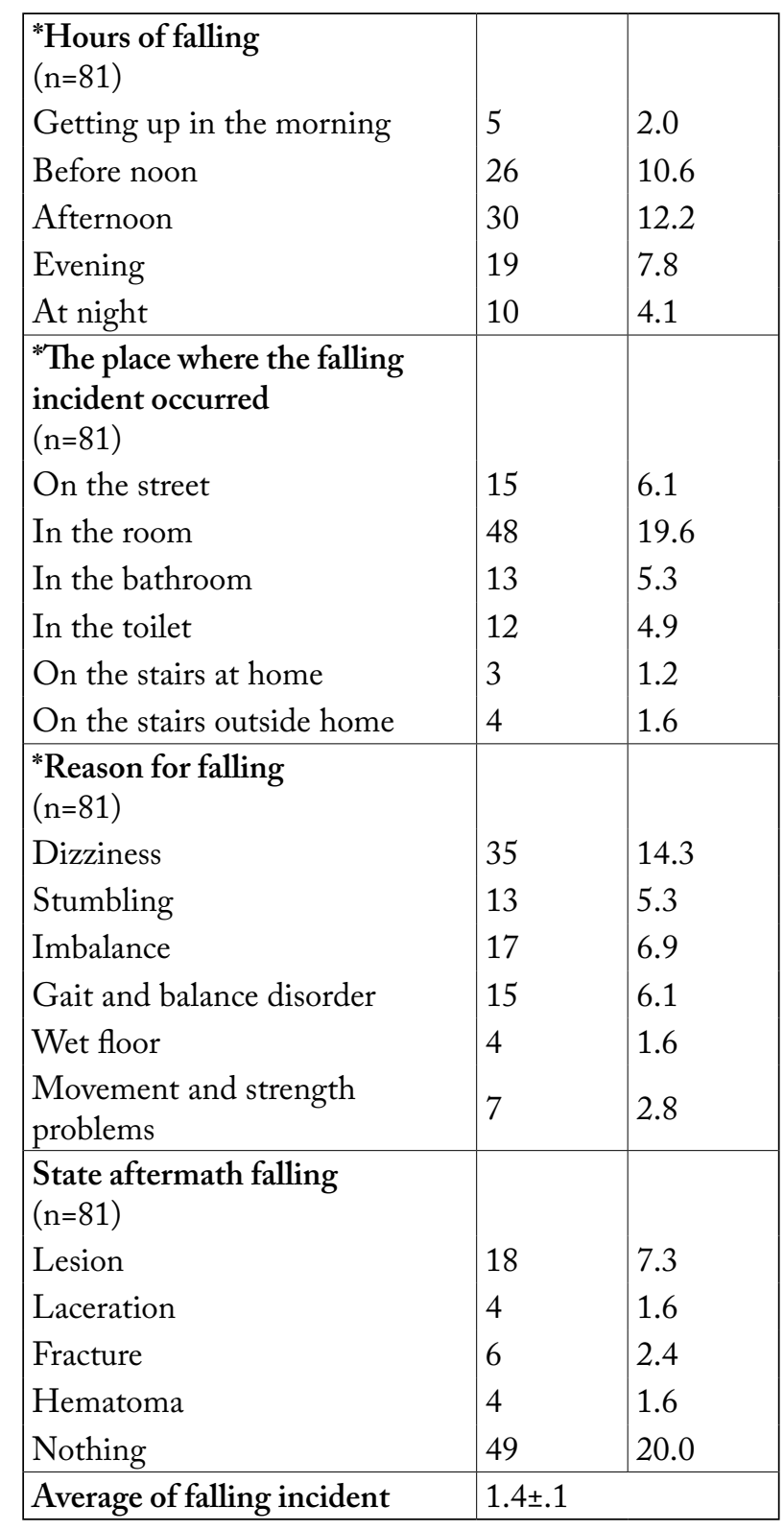

*More than one answer given.

Logistic regression analysis was performed to determine some risk factors affecting falls in neurological patients. Logistic regression analysis showed that the model accurately estimated the risk of falls at $88.2 \%$ and each increase in age unit increased the risk of falls $(p=0.000)$; the residence unit where the patients lived

had a significant impact on the risk of falls, and compared to the patients living in villages, those living in town districts had a 7.9-fold higher risk of falling; the state of health perception also affected falls $(p=0.001)$; compared to the patients with negative perception of health, the risk of falls was 0.09 times higher in those 


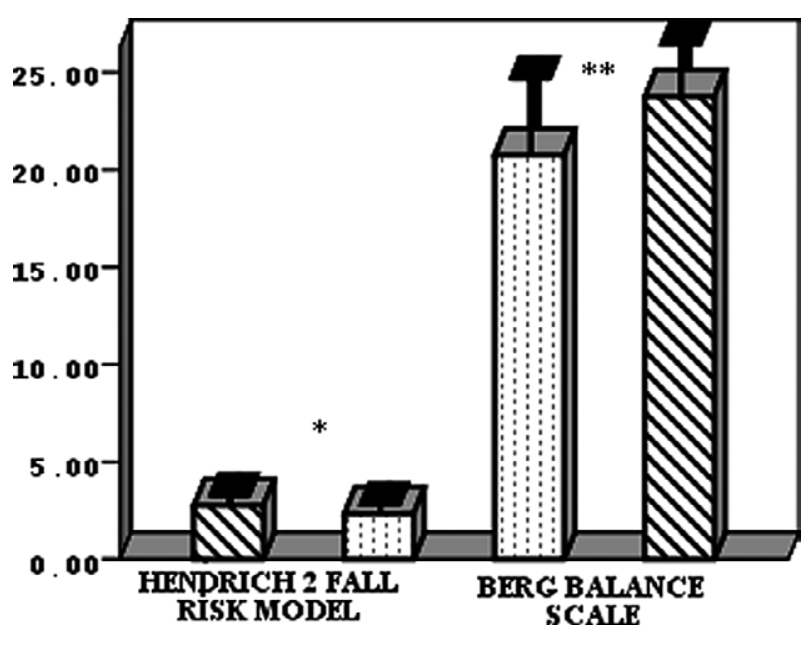

$\mathbb{N}_{\text {FALL }}$

NO FALL

Fig. 1. Distribution of total score of Hendrich II fall risk model and Berg balance scale of patients with and without falls $\left({ }^{*} t=1.590, p=0.116 ;{ }^{* *} t=1.027, p=0.308\right)$.

with good health perception; it was 0.08 times higher in those with moderate level of health perception and 0.18 times higher in those with fear of falling ( $\mathrm{p}=0.013)$. Logistic regression analysis showed that the model accurately estimated balance risk in $89.0 \%$ and that like in falls, each increase in age unit affected balance and increased the risk of falls ( $\mathrm{p}=0.000)$ (Table 4).

\section{Discussion}

Although it has been reported that falls in inpatients cause serious injuries and complications ${ }^{1}$, it was found that the literature contained a limited number of research on the prevalence of risk factors and diagnosis of falls ${ }^{8,10,17}$. This study will contribute to understanding the prevalence, etiology and risk factors in neurological patients in northern Turkey and help develop appropriate guidelines to reduce patient falls.

In the present study, it was found that $11.4 \%$ of neurological patients had a high risk of falling. Lovallo et al. report that $29.69 \%$ of patients had the risk of falling; $70.31 \%$ had no risk of falling; neurology department ranked third in the prevalence of falls $(18.6 \%)$ following oncology (35.6\%) and rehabilitation (20.3\%) departments ${ }^{4}$. Other studies found that neurological patients had a risk of falling ${ }^{8}$; when compared to other services, the rate of fall cases was higher in neurology services $^{5-7}$. As indicated in the literature, arrangements in interior structure of hospitals ${ }^{5}$ and implementation of programs to prevent falls and injuries is of great importance to reduce falls among neurological patients ${ }^{5,6}$.

In the present study, the majority (89.8\%) of $\mathrm{pa}^{-}$ tients had a chronic disease, particularly hypertension and diabetes, and they were taking medication for their chronic diseases regularly. Similarly, Özden et al. report that patients had chronic diseases, mainly hypertension, coronary artery disease, diabetes mellitus $(83.7 \%, 41.8 \%$ and $28.3 \%$, respectively) and that almost all of them (94.6\%) used medication ${ }^{18}$. Stolze et al. report that antidepressants, antihypertensives, diuretics and digitalis are risk factors for falls ${ }^{10}$. Results of the present study suggest that, considering that the majority of neurological patients had chronic diseases and used medication for these diseases, these patients should be closely monitored for the risk of falling and adverse effects of medicines.

It was found that approximately one-third of the study patients $(33.1 \%)$ had fallen during the previous three years. Previous studies determining falls in neurological patients report that fall prevalence varied between $7.2 \%$ and $89.2 \%^{1,9,10,18-20}$. On the other hand, comparison of our findings with those of other studies with similar research methodology showed the prevalence of falls in neurological patients to be higher in other studies ${ }^{10,18,19}$; however, in some other studies, the prevalence of falls was lower as compared with our study $y^{9,20}$.

We found that falls occurred mostly in rooms $(19.6 \%)$ and that the most significant cause of falls was dizziness (14.3\%). On the other hand, other studies found that falls generally occurred inside houses ${ }^{10,18,19}$, outside ${ }^{10}$, in other buildings ${ }^{10}$, in the street ${ }^{18}$, in patient bathroom ${ }^{7}$, toilet ${ }^{18}$, corridor $^{18}$; and that they had fallen due to wet floor ${ }^{10}$, poor lighting ${ }^{10}$, inadequate shoes ${ }^{10}$, walking bare foot ${ }^{10}$, slippery ground $d^{7,10}$, posture and gait disorders ${ }^{10}$, malfunction of wheelchair ${ }^{18}$, fainting ${ }^{7}$, and vertigo ${ }^{9}$. Similar to these findings, previous studies report that falls occurred mostly in patient rooms $\mathrm{s}^{1,6,7,18}$ and that the most important causes of falling were loss of balance and dizziness ${ }^{7,9,18}$. Albernaz and Dos Santos Cabral report that neurological patients experienced loss of balance and dizziness very often, therefore falls were frequent among them ${ }^{9}$. 
Table 4. Some risk factors affecting the status of falls and balance and odds ratio

\begin{tabular}{|c|c|c|c|c|}
\hline \multirow[b]{2}{*}{ Risk factor } & \multicolumn{2}{|c|}{ Hendrich II fall risk model } & \multicolumn{2}{|l|}{ Berg balance scale } \\
\hline & $\begin{array}{l}\text { Odds ratio (95\% } \\
\text { confidence interval) }\end{array}$ & $\mathrm{p}$ & $\begin{array}{l}\text { Odds ratio }(95 \% \\
\text { confidence interval) }\end{array}$ & $\mathrm{p}$ \\
\hline Age & $\begin{array}{l}1.111 \\
(1.052-1.172)\end{array}$ & 0.000 & $\begin{array}{l}0.922 \\
(0.887-0.958)\end{array}$ & 0.000 \\
\hline Gender & & & & \\
\hline $\begin{array}{l}\text { Female } \\
\text { Male }\end{array}$ & $\begin{array}{l}0.450 \\
(0.175-1.157) \\
2.00\end{array}$ & 0.097 & $\begin{array}{l}0.831 \\
(0.331-2.087) \\
2.00\end{array}$ & 0.694 \\
\hline Place of residence & & 0.015 & & \\
\hline City & $\begin{array}{l}2.917 \\
(0.761-11.190)\end{array}$ & 0.119 & $\begin{array}{l}3.895 \\
(0.772-19.653)\end{array}$ & 0.100 \\
\hline Town & $\begin{array}{l}7.972 \\
(1.868-34.027)\end{array}$ & 0.005 & $\begin{array}{l}2.342 \\
(0.382-14.378)\end{array}$ & 0.358 \\
\hline Village & 3.00 & & 3.00 & \\
\hline Perceived health & & 0.001 & & \\
\hline Good & $\begin{array}{l}0.096 \\
(0.014-0.664)\end{array}$ & 0.018 & $\begin{array}{l}3.421 \\
(0.560-20.886)\end{array}$ & 0.183 \\
\hline Fair & $\begin{array}{l}0.086 \\
(0.024-0.313)\end{array}$ & 0.000 & $\begin{array}{l}0.883 \\
(0.157-4.968)\end{array}$ & 0.888 \\
\hline Poor & 3.00 & & 3.00 & \\
\hline $\begin{array}{l}\text { Status of having fear of falling } \\
\text { Yes } \\
\text { No }\end{array}$ & $\begin{array}{l}0.189 \\
(0.051-0.700) \\
2.00\end{array}$ & 0.013 & $\begin{array}{l}0.821 \\
(0.296-2.282) \\
2.00\end{array}$ & 0.706 \\
\hline
\end{tabular}

In the present study, lesion, fracture, laceration and hematoma occurred in patients after falling (7.3\%, $2.4 \%, 1.6 \%$ and $1.6 \%$, respectively). Although types and rates of injuries after falling showed variation in other studies, fractures ${ }^{10,18}$, contusions $s^{6,10}$, soft tissue damage $^{10}$, trauma $^{6}$, abrasion ${ }^{6}$, laceration ${ }^{6,18}$, head inju$\mathrm{ry}^{6,18}$ and chest trauma ${ }^{18}$ occurred after falling.

In the present study, the most important risk factors for falls were age, status of balance and fear of falling. In another study that determined the prevalence, etiology and risk factors for falls it was found that factors such as old age $\mathrm{e}^{8,10,18,19}$, stroke $\mathrm{e}^{21}$, dementia ${ }^{21}$, Parkinson's disease ${ }^{21}$, peripheral neuropathy ${ }^{21}$, depression ${ }^{19}$, vertigo and dizziness ${ }^{8,9}$, posture disorders ${ }^{10}$, gait disor$\operatorname{ders}^{8,10,18,19,21}$, balance disorders ${ }^{8-10,18,19,21}$, history of the last fall ${ }^{8,18,21}$, fear of falls ${ }^{10}$, use of psychotropic medication $^{8}$, antidepressant treatment ${ }^{10}$, neuroepileptics ${ }^{10}$, cardiovascular medicines ${ }^{10}$, use of antihypertensive medicines ${ }^{18}$, change in the level of consciousness ${ }^{18}$, adverse environmental factors in patient house ${ }^{10}$, use of walking aids ${ }^{10,21}$, lower extremity weakness ${ }^{21}$, muscle weakness ${ }^{8}$, use of inappropriate walking aid ${ }^{19}$, sensory losses $^{21}$, problems in bowel and bladder movements ${ }^{8}$, and significant loss of vision ${ }^{8,18,21}$ increased the risk of falls in neurological patients. Although the prevalence, etiology and risk factors in neurological patients varied, we believe that this variation might have resulted from research methodology, socio-demographic and clinical characteristics of the study groups.

We found that patients feared of falls mostly while taking bath; they restricted their movements due to this fear and the rate of falls was increased 0.18 times in those that had fear of falls. In previous studies, $10.9 \%$ of falls occurred in the bathroom ${ }^{7}$; fear of falls was an intrinsic risk factor for falls ${ }^{10}$; and fear of falls might cause reluctance in daily life activities of patients ${ }^{1}$.

In the present study, it was found that falls mostly occurred during the day and in the afternoon. On the other hand, Hitcho et al. report that $58.5 \%$ of falls oc- 
curred between 7 p.m. and 6 a.m. ${ }^{7}$. The fact that falls occurred during the day might result from meeting personal care needs when they are more active. The fact that previous studies found that falls mostly occurred at night might result from problems of patients due to bowel and bladder movements ${ }^{8}$, or they wanted to use bathroom. Lovallo et al. report that $32.2 \%$ of falls occurred at night and 34\% occurred on their way to bathroom; accordingly, going to toilette was a significant risk factor for falls ${ }^{4}$.

Logistic regression analysis performed to determine some risk factors affecting falls of patients revealed the risk of falls to have increased in patients who felt fear of falls and at each age unit increase. Similar to our findings, previous studies have reported that age $\mathrm{e}^{10,18,22}$ and fear of falls ${ }^{10}$ were important risk factors affecting falls. Giles et al. conducted logistic regression analysis and report that confusion, incontinence, mediation, movement and sleep disorders were significant risk factors affecting patient safety among inpatients ${ }^{2}$.

It was found that like in falls, each unit increase of age affected status of balance and increased the risk of falls. Some of the studies report that loss of balance $^{8-10,18,21}$, vertigo ${ }^{23}$ and gait disorder were the most important risk factors in neurological patients, while many risk factors for falls such as gait and balance problems can be modified ${ }^{24}$. Morse reports that due to iatrogenic nature of hospital settings, they are risky places for patients in terms of falls, injuries and deaths, and that health care professionals are responsible for taking protective and preventive measures to eliminate and reduce these risks ${ }^{25}$. As indicated in the literature, considering each etiologic target in hospitals, it is of great importance to understand the use of fall preventive principles and to implement them comprehensively and systematically.

Comparison of the risk profiles of inpatients with those in the society showed variations; hospital environment was found to be much different from home environment, inpatients were generally more frail due to hospitalization, and therefore the measures to reduce falls in hospitalized subjects should be different from those in home setting ${ }^{2}$. In this context, since the present study was carried out in neurological inpatients, it cannot be generalized to different neurological patients in the community. For this reason, future studies should be planned to include neurological $\mathrm{pa}^{-}$ tients in the community, as indicated in the literature ${ }^{17}$; studies should be conducted in individuals with special neurological conditions that might affect gait, movement and balance.

\section{Conclusions}

It was found that approximately one-third of neurological patients had fallen before and they restricted their activities due to fear of falls; in addition, the great majority of them had a chronic disease and permanently used medicines; the most important risk factors for falls were age, fear of falls and balance disorder. Based on these findings, health care professionals are suggested to diagnose fall risk factors with comprehensive assessment (including chronic diseases, medicines, functional condition, house safety, etc.) to reduce the risk of falls, upgrade patient safety and increase mobility of neurological patients. Nurses are recommended to diagnose the risk of falls in all inpatients and to make assessments using fast, easy and practical monitoring tools to reduce and prevent falls in neurological patients. In addition, as indicated in the literature, we suggest the use of exercise programs for balance training ${ }^{17}$. On the other hand, it is of great importance to organize training programs for patients, health care providers and health care professionals to prevent falls.

\section{Acknowledgment}

We would like to thank the elderly for taking part in this study.

\section{References}

1. Schwendimann R. Patient Falls: a Key Issue in Patient Safety in Hospitals. Zürich: Basel University, 2006, doi: 10.5451/unibas-004036746

2. Giles LC, Whitehead CH, Jeffers L, McErlean B, Thompson D, Crotty M. Falls in hospitalized patients. Comput Inform Nurs. 2006;24(3):167-72, doi: 10.1097/00024665-20060500000014

3. Healey F. A guide on how to prevent falls and injury in hospital. Nurs Older People. 2010;22(9):16-22, doi: 10.7748/nop 2010.11.22.9.16.c8060

4. Lovallo C, Rolandi S, Rossetti AM, Lusignani M. Accidental falls in hospital inpatients: evaluation of sensitivity and specificity of two risk assessment tools. J Adv Nurs. 2010;66(3): 690-6, doi: 10.1111/j.1365-2648.2009.05231.x

5. Diccini S, Gomes de Pinho P, Oliveira da Silva F. Assessment of risk and incidence of falls in neurosurgical inpatients. Rev Lat Am Enfermagem. 2008;16(4):752-7, doi: 10.1590/s010411692008000400016 
6. Rohde JM, Myers AH, Vlahov D. Variation in risk for falls by clinical department: implications for prevention. Infect Control Hosp Epidemiol. 1990;11(10):521-4, doi: 10.1086/646085

7. Hitcho EB, Krauss M, Brige S, Dunagan WC, Fischer I, Johnson $\mathrm{S}$, et al. Characteristics and circumstances of falls in a hospital setting: a prospective analysis. J Gen Intern Med. 2004; 19(7):732-9, doi: 10.1111/j.1525-1497.2004.30387.x.

8. Hunderfund ANL, Sweeney CM, Mandrekar JN, Johnson LM, Britton JW. Effect of multidisciplanary fall risk assessment on falls among neurology inpatients. Mayo Clin Proc. 2011;86(1):19-24, doi:10.4065/mcp.2010.0441

9. Albernaz PLM, Dos Santos Cabral FS. Vertigo and dizziness in elderly patients with neurological disorders. Einstein (Sao Paulo). 2011;9(4 Pt 1):466-9, doi: 10.1590/S1679-450820 11AO2131.

10. Stolze H, Klebe S, Zechlin C, Baecker C, Friege L, Deuschl G. Falls in frequent neurological diseases - prevalence, risk factors and aetiology. J Neurol. 2004;251(1):79-84, doi: 10.1007/ s00415-004-0276-8

11. Hendrich AL, Bender PS, Nyhuis A. Validation of the Hendrich II fall risk model: a large concurrent case/control study of hospitalized patients. Appl Nurs Res. 2003;16(1):9-21, doi: 10.1053/apnr.2003.YAPNR2

12. Hendrich A. How to try this: predicting patient falls. Using the Hendrich II fall risk model in clinical practice. Am J Nurs. 2007;107(11):50-8,doi:10.1097/01.NAJ.0000298062.27349.8e.

13. Atay S, San AT, Aycan Ö. Validity and reliability study of Hendrich II Fall Risk Model. $12^{\text {th }}$ National Nursing Congress, 20-24 October, 2009, pp. 217-8; Sivas (in Turkish).

14. Berg K, Wood-Dauphinee S, Williams JI, Williams JI, Gayton D. Measuring balance in the elderly: preliminary development of an instrument. Physiother Can. 1989;41(6):304-11, doi: 10.3138/ptc.41.6.304

15. Muir SW, Berg K, Chesworth B, Speechley M. Use of the Berg balance scale for predicting multiple falls in community-dwelling elderly people: a prospective study. Phys Ther 2008;88 (4):449-59, doi: $10.2522 /$ ptj.20070251
16. Sahin F, Y1lmaz F, Ozmaden A, Kotevoglu N, Sahin T, Kuran B. Reliability and validity of the Turkish version of the Berg Balance Scale. J Geriatr Phys Ther. 2008;31(1):32-7, doi: 10.1519/00139143-200831010-00006

17. Thurman DJ, Stevens JA, Rao JK. Practice parameter: assessing patients in a neurology practice for risk of falls (an evidencebased review). Neurology. 2008;70(6):473-9, doi: 10.1212/01. wnl.0000299085.18976.20

18. Özden D, Karagözoğlu Ş, Kurukız S. Determination of fall risk according to Hendrich II and Morse Fall Scale: a pilot study. Anadolu Hemşirelik ve Sağlık Bilimleri Dergisi. 2012;15(1): 80-8 (in Turkish).

19. Soyuer F, Ünalan D, Erdoğan F. The prevalence and risk factors of fall of the patients applying to the Department of Neurology in Erciyes University Medical Faculty. Türk Nöroloji Dergisi. 2006;12(4):269-74 (in Turkish).

20. Savcı C, Kaya H, Acaroğlu R, Kaya N, Bilir A, Kahraman H, et al. The determination of patients' falling risk and taken preventive measures in neurology and neurosurgery clinics. Maltepe Üniversitesi Hemşirelik Bilim ve Sanatı Dergisi. 2009;2(3): 19-25 (in Turkish).

21. American Academy of Neurology. AAN Summary of Evidence Based Guideline for Clinicians, 2008. Assessing patients in a neurology practice for risk of falls. [cited 2012 September 11]. Available from: www.aan.com.

22. Nakai A, Akeda M, Kawabata I. Incidence and risk factors for inpatient falls in an academic acute-care hospital. J Nippon Med Sch. 2006;73(5):265-70, doi: 10.1272/jnms.73.265

23. Moylan KC, Binder EF. Falls in older adults: risk assessment, management, and prevention. Am J Med. 2007;120(6):493-7, doi:10.1016/j.amjmed.2006.07.022

24. Matejcic A, Bekavac-Belin M, Ivica M, Tomljenovic M, Krolo I, Vucetic B. Fractures of the proximal femur in the elderly. Acta Clin Croat. 2002;41:15-23.

25. Morse JM. Enhancing the safety of hospitalization by reducing patient falls. Am J Infect Control. 2002;30(6):376-80, doi. org/10.1067/mic.2002.125808 


\title{
Sažetak \\ UČESTALOST PADOVA, NJIHOVA ETIOLOGIJA I ČIMBENICI RIZIKA KOD NEUROLOŠKIH BOLESNIKA PRIMLJENIH U BOLNICU U SJEVERNOJ TURSKOJ
}

\author{
Z. Koç, A. Memişi Z. Sağlam
}

Proveli smo presječno deskriptivno istraživanje kako bismo utvrdili učestalost padova, njihovu etiologiju i rizične čimbenike kod neuroloških bolesnika primljenih u bolnicu u sjevernoj Turskoj. Prikupljeni su podaci kojima su utvrđene sociodemografske i kliničke karakteristike ispitanika, model rizika za pad Hendrich II. i Berg balance scale (BBS). Rezultati su pokazali da je otprilike jedna trećina bolesnika uključenih u istraživanje (33,1\%) već prije doživjela pad, pri čemu se $24,9 \%$ takvih incidenata dogodilo tijekom protekle godine. Omaglica je bila najčešći razlog za pad (14,3\%). Srednji zbir u modelu

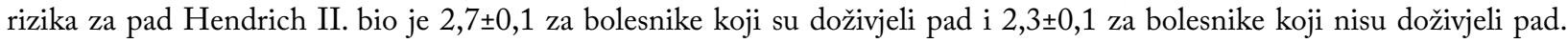

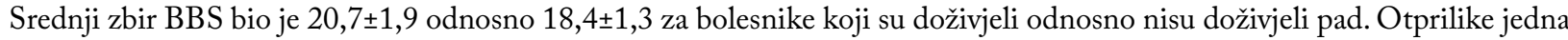
trećina neuroloških bolesnika već je prije doživjela pad pa su ograničili svoje aktivnosti zbog straha od pada. Velika većina bolesnika imala je kronične bolesti i trajno su uzimali lijekove. Najvažniji čimbenici rizika za pad bili su poodmakla dob, strah od pada i poremećaj ravnoteže.

Ključne riječi: Ravnoteža; Etiologija; Pad; Neurologija; Učestalost; Prevencija; Rizik 